\title{
Albers-Schönberg osteopetrosis
}

INSERM

\section{Source}

INSERM. (1999). Orphanet: an online rare disease and orphan drug data base. Albers-

Schönberg osteopetrosis. ORPHA:53

Albers-Schönberg osteopetrosis is a sclerosing disorder of the skeleton characterized by increased bone density that classically displays the radiographic sign of "sandwich vertebrae" (dense bands of sclerosis parallel to the vertebral endplates). 